\title{
Roger Herschel Herzig: younger half of the dynamic duo which advanced leukaemia therapy and transplants: January 4, 1946 to July 18, 2020
}

\author{
Robert Peter Gale $\mathbb{D}^{1} \cdot$ Hillard M. Lazarus ${ }^{2} \cdot$ Gordon L. Phillips ${ }^{3}{ }^{3}$
}

Received: 30 July 2020 / Revised: 5 August 2020 / Accepted: 11 August 2020 / Published online: 9 September 2020

(c) The Author(s), under exclusive licence to Springer Nature Limited 2020

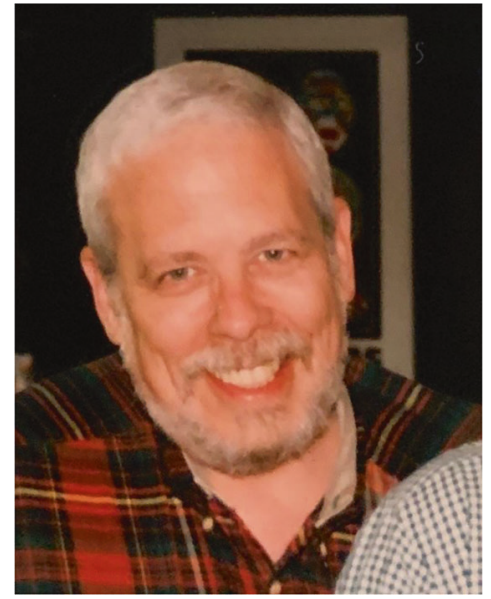

Roger H. Herzig, a pioneer in leukaemia therapy and younger brother of Geoffrey M. Herzig (Bone Marrow Transplantation 2014;49:597-8) died on July 18, 2020, age 74 years. His death is a loss to the haematopoietic cell transplant and leukaemia communities, his patients to whom he was extraordinarily dedicated and his family. He left a legacy of loyalty, commitment, courage and love.

Roger was born in Cincinnati. His undergraduate studies were at the University of Cincinnati and his medical training in Cleveland at Case Western Reserve

Robert Peter Gale

robertpetergale@alumni.ucla.edu

1 Haematology Research Centre, Department of Immunology and Inflammation, Imperial College London, London, UK

2 Department of Medicine, Division of Hematology and Oncology, Case Western Reserve University, Cleveland, OH, USA

3 Wake Forest University Comprehensive Cancer Center, Winston Salem, NC, USA
University. Curiously, his internship was in obstetrics and gynaecologist and his residency, general surgery. During the Korean and Vietnam Wars (1953-1973), the brightest young physicians inducted into the military under the Doctors Draft had the option to go the National Institutes of Health in an Associate Training Programme [1]. They called themselves Yellow Berets. Interestingly, graduates of the programme were 1.5 times as likely as non-associates to become full professor, twice as likely to become department chairs and three times as likely to become deans. Associates were also more likely to hold positions at top-ranked medical schools, fill leadership roles at the NIH and win prestigious awards and honorary society memberships.

The condition of acceptance was that you had to go to the NIH Institute, which chose you. Imperfect, but better than being sent to Ho Chi Minh City (nee Saigon). Fortunately for us and people with leukaemia and lymphoma, Roger was vetted to the Oncology Branch of the National Cancer Institute, not the National Institute of Child Health and Human Development. There he worked with early leukaemia and haematopoietic cell transplant pioneers including Robert Graw Jr, Malcolm and Jane Bull, David Poplack, Brigid Leventhal, Ronald Yankee, Archie Bleyer, Edward Henderson and Geoff where he helped design therapies to treat people with leukaemias and lymphomas. In 1975, Roger returned to University Hospitals Cleveland Medical Center for a haematology/oncology fellowship, like taking classes after receiving your graduate degree. In 1976, Roger founded the Bone Marrow Transplant Programme at University Hospitals. On medical rounds, Roger and HML were referred to as the Broviac Brothers after the indwelling venous catheters many acutely ill patients needed. In 1984, Roger moved to the competition, the Cleveland Clinic and in 1988 to Louisville to direct the University of Louisville James Graham Brown Cancer Centre. In 2014, he moved to the University of Kentucky Markey Cancer 
Centre in Lexington but planned a return to the University of Louisville.

Through nearly 50 years of medical practice he touched countless lives, educated several generations of physicians and helped establish bone marrow transplant programmes internationally. He was a member of many learned societies such as the American Society of Hematology, the American Society of Clinical Oncology, the International Society of Experimental Hematology and an Honorary Professor of the Chinese Academy of Medical Sciences and Peking Union Medical College.

Roger published more than 100 typescripts including 34 with Geoff. Interestingly, his 1 st publication was with Prof. Oscar Ratnoff, widely credited with unravelling the blood coagulation cascade. Their study was on the procoagulant activity of southern copperhead snake venom. This may have been good preparation for a career in academic medicine; poisonous snakes are everywhere. Prof. James Armitage, Roger's colleague and friend, and a noted herpetologist and snake bite expert, would be proud that he knows Roger.

Roger formed close collaborations for clinical trials with Geoff and with HML, GLP, David Hurd, Steven Wolff, Joseph Fay and others in the North American Marrow Transplant Group, a small but highly productive clinical trials consortium. Several of their outstanding contributions were studies of high-dose cytarabine for acute leukaemia for relapse and later for consolidation, bone marrow autotransplants for advanced lymphomas and high-dose melphalan in haematopoietic cell transplants. We use these therapies today

Prof. Herzig rotated between three sites; (1) home with his wife Donna and four sons; (2) the hospital and clinic; and (3) the racetrack, notably Churchill Downs (home of the Kentucky Derby) and Keeneland. In the hospital he was also known as the Louisville slugger. Whether Roger left Cleveland for Kentucky because of his interest in horse racing or developed it there is unclear. He could be found at the track with a pitcher of Diet Coke and a basket of pretzels; he indulged in a mint julip on special occasions such as the Derby. Roger was considered a racetrack sage. His advice (we provide a guide for the rare reader unfamiliar with the nuances of race track betting): (1) not a man alive made a dime at 4-5; (2) never bet a trifecta; bet the exacta (a bet on which horses will finish 1st and 2nd in the exact order rather than 1st, 2nd and 3rd); (3) wheel the favorite (some statistics: in a eight horse race there are 56 possible combinations for 1 st and 2 nd place. In a wheel you pick a horse to win and 4 other horses to potentially come in 2 nd); and (4) when in doubt, bet on Pat Day (Day, a jockey, won 8803 races and is the all-time leader in monies earned winning nine Triple Crowns). The last advice is beyond its sell buy date. Day retired in 2005, but Roger's other tips will stand you in good stead and likely make you rich. Disclaimer: RPG lost $\$ 50$ at Churchill Downs on a tip he received from Roger over several Kentucky bourbons (Blanton's Single Barrel of course) at the Seelbach Hotel. (More information on how to become rich at https://www. thesportsgeek.com/sports-betting/strategy/horse-racing/).

A Man for All Seasons, Roger was part-owner of Northern Emerald, a horse which raced at Belmont park. One of his dogs won Best in Show at the Westminster Dog Show. He had a cameo role in the TV show One Life to Live. He loved to say: I'm a doctor playing one. A gracious person, he never had a Cromwell or a Henry VIII. Although Roger and Geoff were not genetically identical or even fraternal twins, Roger was never really the same after Geoff died. They were terribly close.

Roger Herzig made important contributions to our current therapies of leukaemias, lymphomas and other cancers. $\mathrm{He}$ is survived by his wife, his sons David, Daniel, Robert and Brian and nine grandchildren. He will be greatly missed but his legacy lives on. GLP adds an Oklahoma farewell: ya done good. You could always bet on Roger and win; forget the ponies.

Acknowledgements RPG acknowledges support from the National Institute of Health Research (NIHR) Biomedical Research Centre funding scheme.

\section{Compliance with ethical standards}

Conflict of interest The authors declare that they have no conflict of interest.

Publisher's note Springer Nature remains neutral with regard to jurisdictional claims in published maps and institutional affiliations.

\section{Reference}

1. Khot S, Park BS, Longstreth WT Jr. The Vietnam War and medical research: untold legacy of the U.S. Doctor Draft and the NIH "Yellow Berets". Acad Med. 2011;86:502-8. 